Revista Iberoamericana, Vol. LXX, Núm. 207, Abril-Junio 2004, 521-544

\title{
LOS PODERES DEL HORROR: FACUNDO COMO EPIFÓRICA ${ }^{1}$
}

\author{
POR \\ Elías Paltí \\ Universidad Nacional de Quilmes
}

\author{
He visto que cuando las cosas buscan su curso, \\ encuentran su vacío \\ Federico García Lorca (“Intermedio”)
}

Facundo (1845), obra que quiso ser muchas cosas al mismo tiempo -una novela, una biografía, un manifiesto doctrinario, un tratado sociológico, un programa políticoterminaría siendo, por sobre todas estas cosas, el testimonio de una derrota, o, más específicamente, de la profunda crisis conceptual que ésta generó. La debacle de los alzamientos contra Rosas, iniciada con el fracaso de la expedición de Lavalle en 1840, dislocaba todas las certezas en que se fundaba el pensamiento de la Generación del '37, minando el supuesto de la racionalidad del curso histórico. Éste, de hecho, se volvería insostenible una vez que el "tirano", tras derrotar toda oposición, se demostrase, aunque irracional, absolutamente real. La Historia en el Plata se poblaría entonces de fenómenos extravagantes, ajenos a todo designio o lógica, incomprensibles, en fin, para la razón. Facundo, en definitiva, nace de esa crisis de inteligibilidad; representa un intento de asir aquello inconcebible, para Sarmiento, un fenómeno inaudito y sin antecedentes conocidos: el poder rosista. Y, fundamentalmente, revelar qué es lo inaudito en él, aquello monstruoso, indefinible racionalmente.

MIMÇSIS, HISTORIA Y REPRESENTACIÓN

Un viejo cuento judío ${ }^{2}$ narra la historia de un rabino de Cracovia que súbitamente interrumpió sus plegarias para anunciar que acababa de ver la muerte de su par de Varsovia (ciudad situada a quinientos kilómetros de allí). Los judíos de Cracovia quedaron, por supuesto, conmocionados ante su poder visionario. Unos pocos días más tarde, algunos de ellos viajaron a Varsovia, y vieron, para su sorpresa, al rabino de esta ciudad trabajando

${ }^{1}$ Este trabajo es un extracto de una obra titulada Distopias. Mimesis and Representation in Times of Revolutions and Wars (Nineteenth-Century Literature in Mexico, Argentina, and Brazil), en preparación.

${ }^{2}$ El relato aparece en Hirschman, The Passions and the Interests. Political Arguments for Capitalism before Its Triumph (117). 
en su sinagoga en un estado de salud, digamos, aceptable. Al volver a Cracovia y dar noticia de lo visto, las previsibles murmuraciones contra el rabino local crecieron al punto que sus más fieles seguidores se vieron obligados a salir en su defensa. Tras admitir que, en efecto, había errado en cuanto a los detalles, exclamaron: "De todos modos, iqué visión la suya!”.

Albert Hirschman, comentando esta historia, afirma que la misma "ostensiblemente ridiculiza la habilidad humana para racionalizar creencias enfrentadas ante la evidencia que la contradice. Pero, a un nivel más profundo, celebra el pensamiento especulativo y visionario, no importando si el mismo se descarría” (117). Indudablemente, como afirma Hirschman, esta tendencia humana a aferrarse a certidumbres que, en apariencia, se habían visto desmentidas por la ocurrencia de hechos no previstos no tiene nada de "irracional" (lo mismo, de hecho, ha sucedido con todas las grandes teorías científicas, las que se han desarrollado simplemente dejando de lado como impertinentes aquellos datos que, en principio, parecían cuestionar su validez). Los defensores del rabino del cuento bien podían todavía pensar, por ejemplo, que éste efectivamente había tenido una visón, si no de lo que ocurrió, sí de lo que pronto iba a ocurrir (y difícilmente podría ningún acontecimiento todavía imprevisto, ningún “dato” posterior, conmover su fe en los poderes visionarios de su rabino: sin duda, el rabino polaco alguna vez iba a morir). La historia sirve así de ejemplo a algo que los epistemólogos han señalado recientemente. ${ }^{3}$ En definitiva, desde el momento en que todo hecho, para ser significativo, es decir, para convertirse en un “dato”, requiere de un cierto marco teórico cuya validez presupone, no puede, por lo tanto, refutarlo sin destruirse a sí mismo también como tal dato. Pero, por otro lado, los “datos” sólo plantean “anomalías” precisamente a aquellas teorías a cuyas premisas invocan y acogen (puesto que de lo contrario resultarían simplemente irrelevantes para las mismas). Cómo es esto posible es algo que los epistemólogos no alcanzan a explicar (probablemente, porque hacerlo escapa al ámbito estricto de la epistemología); pero lo cierto es que las teorías son, en determinado momento, "refutadas”; las creencias, abandonadas o puestas en cuestión; y los "poderes visionarios”, despreciados como un simple engaño o ilusión. La trayectoria intelectual de la llamada Generación del '37 en Argentina resulta quizás un buen ejemplo de cómo creencias profundamente enraizadas son capaces de resistir y adecuarse ante el embate de hechos imprevistos que, en un primer momento, parecen socavar sus mismas bases; pero, también, de cómo éstas se irían problematizando y contorsionando hasta ceder a la emergencia de marcos conceptuales ya definitivamente alejados de sus premisas originales. ${ }^{4}$

En efecto, para la Generación del '37, la afirmación de Rosas producida en torno al año 1842 pondría en cuestión un determinado marco genérico-conceptual (en este caso, el historicista romántico), entendido esto no en el sentido de un sistema de ideas dado, sino algo aún más fundamental: la serie específica de supuestos implícitos, nunca completamente articulados, que les permitía atribuir verdad o falsedad a un enunciado y que definen el

\footnotetext{
${ }^{3}$ Ver Wolfgang Stegmüller, Estructura y dinámica de teorías.

${ }^{4}$ Hans Blumenberg, en Die Genesis der kopernikanischen Welt, describe de un modo análogo el proceso que conduce a la llamada "revolución copernicana”. Sobre dicha perspectiva epistemológica, ver Palti, "Reseña-Ensayo: Hans Blumenberg. Sobre la modernidad, la historia, y los límites de la razón” y reproducido en Palti, Aporías. Tiempo. Modernidad. Sujeto. Historia. Nación. Ley.
} 
contexto particular de producción de los textos analizados. Digamos, para tomar un término acuñado por Koselleck, lo que la consolidación del “régimen bárbaro” viene a frustrar es un cierto "horizonte de expectativas" (Erwartungsraum), aquello que hasta entonces sostenía la certidumbre de "estar en lo cierto" respecto al comportamiento previsible de la sociedad y la historia y confería inteligibilidad a sus acciones. Y ello no porque contradecía ciertas máximas relevantes, sino porque planteaba un dilema; lo que abriría necesariamente para los miembros de dicha generación una "quiebra de inteligibilidad” (una “experiencia abismal”, en el sentido de Nietzsche).

Facundo de Sarmiento es, según se intenta demostrar aquí, aquella obra en que la situación dilemática que la afirmación del régimen rosista plantea a la Generación del ‘37 se plasma literariamente. En ella Sarmiento habría de radicalizar las aristas problemáticas resultantes de esa contradicción fundamental que la afirmación del poder de Rosas venía a plantear a la Generación del '37, lo que le permite explorarla conceptualmente y explotarla literariamente. Entre los miembros de su generación, sólo Sarmiento afirmaría simultáneamente la fatalidad histórica del curso necesario del progreso de la civilización ${ }^{5}$ y, a la vez, la idea de que, aunque se trataba de un fenómeno absolutamente irracional y extraño a dicho curso, el poder de Rosas no era, sin embargo, un incidente circunstancial y pasajero. De allí su "singularidad histórica": el mismo no era un acontecimiento peculiar en el sentido de que se apartaba de las leyes de la Historia colocándose al margen de su alcance (no había nada, para Sarmiento, que pudiese hacerlo, puesto que la universalidad de su aplicación forma parte del mismo concepto de la ley natural o histórica), sino porque las trastrocaba, algo, en principio, inconcebible y que Sarmiento se propone justamente tratar de entender y explicar. A fin de representar dicho fenómeno anómalo, debería, en fin, torsionar el régimen mimético que se encontraba en la base del sistema de saber romántico-historicista y de su modo característico de figuración de la nación. Veamos brevemente cuál era éste.

El concepto de mimçsis physeôs no admite una definición unívoca. Los debates en torno del mismo tienen una larga data, que remiten a la Antigüedad clásica. La noción griega de mimçsis, usualmente asociada con la idea de imitación de la Naturaleza, tuvo, en realidad, una historia y un significado complejo y cambiante. De hecho, en sus orígenes designaba el asumir el papel de otro. Fue en el período clásico que adoptó el sentido de copiar la apariencia externa de las cosas, el cual se convertirá en la base de la teoría del arte dominante por varios siglos. La misma fue establecida por Platón y Aristóteles, pero aun entonces su sentido permanecerá ambiguo, coexistiendo, en perpetua tensión, con muchas otras definiciones del término. Además de ésta, a la que Tatarkiewicz designa como "socrática", dicho autor distingue, en el mundo antiguo, al menos tres significados adicionales (301-24). Para Demócrito, se trataba de la imitación de los modos en que la naturaleza funciona (según afirmaba, cuando tejemos imitamos a la araña; cuando edificamos, a la golondrina; cuando cantamos, al cisne y al ruiseñor). Tenemos aquí la noción de mimçsis como Acción. Aplicado a la música, dicho término alteraría incluso más radicalmente su sentido, denotando no la reproducción de la realidad externa sino la

\footnotetext{
5“Hay una ley dada por Dios a las sociedades humanas, cuyos efectos vemos sin que alcancemos a comprender la ley de los cambios sucesivos, de marcha lenta pero que no retrograda jamás; ley, en fin, de perfección sucesiva, ley de progreso” (Sarmiento, “Origen de la fiesta de Nochebuena”, 91).
} 
expresión de la realidad interna. Ésta es la que Tatarkiewicz llama la noción "ritualista". Finalmente, encontramos la visión de Aristóteles. A la misma normalmente se la asocia con la noción tradicional de imitación de la Naturaleza externa; sin embargo, como muestra Tatarkiewicz, su concepto era más complejo que éste. Aristóteles, dice, “sostuvo la tesis de que el arte imita la realidad, pero la imitación artística no significaba, para él, una copia fidedigna, sino un libre enfoque de la realidad; el artista puede presentar la realidad de un modo personal” (303). El concepto de Aristóteles será así, pues, el resultado de la fusión de las nociones socrática (como copia) y ritualista (como expresión), lo que le permite aplicarla tanto a la música y la escultura como al teatro.

Otros estudiosos han cuestionado esta perspectiva introduciendo nuevos matices y bifurcaciones en la historia de la definición de dicho concepto. Trazar todos los debates que se plantearon escapa al alcance del presente estudio. Sin embargo, la visión de uno de esos autores, Paul Ricoeur, resulta aquí, por razones que luego veremos, particularmente relevante. En La métaphore vive, Ricoeur provee una perspectiva mucho más sutil y provocativa del concepto de mímesis de Aristóteles. ${ }^{6}$ Según muestra, para Aristóteles no había mímesis excepto de una acción. Para él no sería posible, por lo tanto, la imitación de la Naturaleza. No obstante, Ricoeur llama la atención al uso de Aristóteles del término physis con relación con el de mimçsis. Según afirma, toda imitación es aun, para éste, imitación de la Naturaleza (mimçsis physeôs). Esta aparente contradicción no es realmente tal. El término physeôs, que convierte la mimçsis en imitación de la Naturaleza, sólo nos recuerda aquí el hecho de que toda creación conlleva siempre una referencia a la realidad; en suma, que toda poiesis reenvía a una metafísica, tiene implícita una dimensión ontológica.

En efecto, según muestra Ricoeur, el artista que intenta representar la realidad debe poseer ya una idea de aquella realidad a representar. La tarea del crítico tendría, así, una doble dimensión: además de observar los medios por los cuales el artista representa la realidad, debe tratar de comprender qué era lo que intentaba retratar, cómo su objeto había sido construido conceptualmente. Y, eventualmente por qué éste es concebido como no representable. Esto es, cómo la realidad es construida de un modo que no se preste a sí misma a la representación. Encontramos aquí la definición concisa del objeto en torno del cual gira el presente estudio. La pregunta crucial que el tipo de experiencia abismal que intentamos describir hace surgir es cómo es posible que una realidad conceptualmente construida pueda aparecer como desafiando las propias premisas a partir de las cuales ésta fue concebida.

Esto nos devuelve al concepto romántico-historicista que se encuentra en la base del régimen de saber que Sarmiento tenía disponible para intentar pensar la nación, el vocabulario de base sobre el que se levanta su perspectiva. Las ideas del siglo XIX tanto de la Naturaleza como de la Historia suponían un modo específico de representación, un régimen mimético particular, el cual no era ya el ideal clásico que buscaba reproducir las formas externas de los fenómenos. La "referencia ontológica” de que habla Ricoeur (lo Real como Acción) remite, en este contexto, a la visión de la Naturaleza (y la Historia) propia a las teorías evolucionistas-organicistas que emergieron en el curso del siglo XIX.

\footnotetext{
${ }^{6}$ Para él, la perspectiva de Tatarkiewicz sería presa aún de la dicotomía entre representación objetiva
} y expresión subjetiva que dominó la teoría estética occidental hasta muy recientemente. 
Las mismas concebían a ésta como esencialmente productiva, energeia antes que ergon, según la definición de Alexander von Humboldt (la característica distintiva de la Naturaleza concebida como organismo era, alegadamente, su capacidad de autogeneración y autodesarrollo). Imitar la Naturaleza de forma artística implicaba así representar, y, de algún modo, reproducir el modo en que ésta funciona (y lo mismo podría decirse respecto de la Historia). El punto aquí, en fin, es tratar de comprender cómo este concepto específico de la Historia (i.e., como Acción) habría de ponerse en crisis y su régimen mimético implícito (mimçsis physeôs) habría de torsionarse a fin de volver representable aquellos fenómenos y acontecimientos de la historia nacional que aparecerían como irrepresentables, inconcebibles racionalmente.

LA FÓRMULA “CIVILIZACIÓN Y BARBARIE”: SU EMERGENCIA Y RESEMANTIZACIÓN TRAS LA DERROTA

Una mirada al contexto en que surge Facundo ilumina el tipo de dilemas que enfrentaba su autor en el momento de su composición. Entre los miembros de la Generación del '37, a los que Sarmiento se une en el exilio, éste fue quien más resistió a admitir la afirmación del poder rosista como algo definitivo. Simplemente no podía aceptar que, como afirmaban los "hombres de Europa", "Rosas es invencible, tiene opinión y la libertad ha perdido para siempre sus títulos en el suelo argentino” ("La cuestión del Plata” 77). Todavía en 1841, "después que todos han desesperado de la salvación de la patria” (“Segundo comunicado” 59), confiaba en que la suerte de la lucha contra el "tirano" no había sido aún decidida, que el orden natural de las cosas pronto volvería a su quicio. Entonces, decía, podría verse hasta qué punto las peripecias hasta ese momento sufridas en la contienda portaban un sentido oculto. ${ }^{7}$ Comprender filosóficamente la Historia era, para él, penetrar su caos aparente y acceder al orden que le subyace. ${ }^{8}$ "Gloriémonos", inisistía en el prospecto inaugural de su nueva empresa editorial, El Heraldo Argentino, "de pertenecer a esa raza de titanes que saca nuevas fuerzas de sus quebrantos y no desesperemos del porvenir de nuestra patria”, "la guerra que nuestros compatriotas hacen al tirano está a punto de dar resultados decisivos” (“Prospecto...” 94 y 97).

El tono épico que entonces adopta trasluce, de todos modos, un sentido de urgencia nuevo en él. Sabía, al menos, que la que según él se avecinaba no iba a ser una batalla más, que la historia en el Plata estaba aproximándose al momento de su krisis ("las ideas retrógradas y sus consecuencias, luchan por la última vez”, decía, “con las ideas de la libertad, de constitución y de progreso”) (“Política americana” 11). Al año siguiente, el triunfo de Paz en Caaguazú devolvería las cosas a su curso natural.

\footnotetext{
7 "Si se ven, en fin, como borrados los elementos discordantes que estorban por doquiera una organización cualquiera, estaremos dispuestos a aceptar el período que ha preparado el momento presente, como un momento de alto que ha hecho la regeneración política, para reorganizar mejor sus fuerzas, para explorar el terreno que pisa, para apreciar mejor los obstáculos con los que tiene que luchar" ("Política americana” 17).

8“"Tal es la época actual”, aseguraba, "que se ocupa de explicar los hechos históricos y de colocarlos, no en el orden cronológico en que se han sucedido, sino en el orden progresivo de los desenvolvimientos de las sociedades" ("Vindicación...” 9).
} 
El General Paz, triunfando en los campos de Caaguazú, ha restablecido la lucha que había parecido extinguirse con las derrotas que Lavalle y Lamadrid habían sufrido en el Interior. Tres provincias se han escapado al poder del tirano, y lejos de abandonarse a la inacción, se preparan para romper las cadenas de toda la República (“Conducta de Rosas...” 3435).

Caaguazú era, para Sarmiento, la comprobación empírica de que no se podían burlar gratuitamente las exigencias de la razón: ésta habría de encontrar, tarde o temprano, las vías para imponerse. Sin embargo, pronto descubriría que la insobornable facticidad se obstinaba en resistir a los designios racionales:

Los hechos suelen a veces desmentir todas las probabilidades, salirse del círculo de lo que considerábamos posible, y romper bruscamente el hilo de las promesas más bien fundadas, para representar su cara desnuda, positiva, burlándose irónicamente de los juicios humanos... ¿El sentido común no escarnece y rechaza esta fábula que tan absurda parece?... ¿Vióse fenómeno más raro, más incomprensible, más disparatado? (“Comentario...” 47-48)

Paz había sido nuevamente atrapado; y con ello, las resistencias a Rosas parecían llegar a su fin. Son “los altos destinos de la Providencia”, decía, “que gusta a veces burlarse del orgullo de la razón humana” (“Comentario...” 49). El hecho y la forma en que había sido derrotado no podían haber importado un contraste más brutal a las expectativas de Sarmiento. Se imponía repensar todo aquello en lo que había hasta entonces confiado. Todos sus modelos se habían derrumbado.

No tenemos un solo modelo en el mundo que imitar, porque esta cuestión está viva en todas partes, y los hechos consumados no han dado hasta ahora una solución completa. ¿Qué hay en Francia sobre la ley electoral, por ejemplo, que es la base de los sistemas representativos? Anarquía de intereses e ideas. ¿Qué hay en Inglaterra y en España? Anarquía. ¿Qué hay actualmente en Chile? Anarquía. (“Ensayo sobre la vida...” 245)

Este segundo semestre del año '42 va a marcar decisivamente el pensamiento de este autor. La anarquía parecía en esos momentos impregnarlo todo. Aún entonces, sin embargo, resistiría a conformarse con las explicaciones locales, que atribuían este desenlace a circunstancias particulares al medio argentino. " "No se tiene presente", decía, que Argentina “es la más cercana a la Europa” ("La cuestión del Plata” 91). "El fenómeno no puede ser más extraordinario, ni más digno de llamar la atención de la América” "“La cuestión del Plata” 70). Sería un error gravísimo, aseguraba, pensar "que se trata de una vulgar guerra civil”, "no se ha comprendido que ella es singular en su género, que se trata”, decía, “nada menos que de arrojar la civilización” (“La cuestión del Plata” 74), lo que para

\footnotetext{
9 “Cansados estamos de soluciones fáciles para explicar este fenómeno, deducidas de circunstancias particulares a cada estado, como ser la ambición de este o aquel caudillo particular... Necesitaríamos otras más profundas y generales y que pudiesen servir y fueran aplicables a todos los casos” (“Política americana” 7).
} 
Sarmiento quería decir algo así como alcanzar el fin de la Historia sin que ésta llegase a su Fin, a su remate obligado -la civilización, cuya consecución quedaría, según parece, ya erradicada definitivamente como posibilidad (de lo contrario, cabría considerar aún al régimen de Rosas como un mero obstáculo temporal en la marcha triunfal de aquella). Qué significaba esto, cómo sería ello posible, cuáles sus consecuencias, qué vendría después, eran cuestiones a las que todavía no alcanzaba a comprender del todo bien. La búsqueda de categorías que permitieran descifrar tal dilema, hacer comprensible el significado de esto que llama una "nueva era”, por no tener aún un mejor término para definirla, en que la civilización quedaría barrida como alternativa, se traducirá en un giro conceptual que llevará directamente a Facundo.

La cuestión presente del Plata no es la misma enteramente que la que se agitaba en los años '30 y '31. Entonces, como ahora, se luchaba entre el absolutismo y la libertad, entre la barbarie y la civilización; pero hay algo más en la lucha actual que le da diferente aspecto, al menos para el exterior. Aquella guerra pudo llamarse guerra civil..., pero desde que Rosas logró enterrar a sus dignos compañeros, desde que quedó solo en el campo... comenzó una nueva era. (“La cuestión del Plata” 71)

Lo que los demás miembros de su generación no comprendían, aseguraría entonces, es que ésta no era una vulgar guerra civil, que se trataba de una lucha entre civilización y barbarie. Y esto cambiaba completamente la naturaleza de la cuestión. Considerada como un enfrentamiento entre puros principios en tanto que tales, podría aceptarse que su destino sólo habría de resolverse en los fragores mismos de la contienda: aquél que lograra montar una fuerza superior habría necesariamente de alzarse con el triunfo. Y, en efecto, suele suceder que las fuerzas retrógradas se imponen ocasionalmente en la historia, como ocurrió en Europa con la Restauración, sin que ello represente nada particularmente dramático -más allá de lo que imponen las mismas contingencias históricas. No será así, sin embargo, para Sarmiento, desde el momento en que la lucha se plantee estrictamente en los términos de un enfrentamiento entre “civilización” y "barbarie”. En este caso, el triunfo, parecía decir Sarmiento, sólo podría corresponder a la primera. Simplemente, porque un triunfo de la "barbarie" sería entonces inconcebible, algo inaudito, sin comparación posible con lo que fuera la imposición de las fuerzas conservadoras en la Europa civilizada.

En fin, a medida que avanzaba la situación hacia un desenlace que imaginaba trágico, el pensamiento de Sarmiento parece replegarse sobre sí para encontrar en su seno las garantías que una realidad esquiva ya no podía brindarle. Es entonces cuando la fórmula de "civilización” y "barbarie" comienza a ocupar un primer plano como el reaseguro conceptual último (instancia que se vuelve decisiva cuando otras parecen desvanecerse) a la promesa de un triunfo pleno de la empresa civilizadora. Difícil es imaginar cómo pensaba que habría de ocurrir este anunciado estrepitoso y glorioso derrumbe del poder tiránico. De todos modos, lo cierto es que ello no iba a ocurrir y Sarmiento pronto podría comprobarlo. El once de enero de 1843 proclama desde las páginas de El Progreso: "La catástrofe... ha sobrevenido al fin, después de haberse hecho esperar por mucho tiempo, después de haber burlado todas las conjeturas, contrariado todas las esperanzas y confundido todos lo cálculos” (“La revolución argentina” 98-99). Tras la batalla de 
Arroyo Grande, Oribe (aliado de Rosas) ocupaba la Banda Oriental y ponía sitio a Montevideo. "Los argentinos residentes en Chile”, decía, "proscriptos de su patria, pierden desde hoy la nacionalidad” (“Despedida...” 104). Según reconoce finalmente:

La larga lucha queda terminada. No más sonará en la ancha extensión de la República Argentina el cañón de la discordia de la guerra civil... La oposición no sólo ha sido herida de muerte, vencida, aterrada, sino que se le ha cortado la cabeza, ha sido segada del haz de la tierra, y sembrado de sal el suelo en que antes germinaba. ("La revolución argentina" 99).

El campo de batalla de las puntas del Arroyo Grande ha sido el tribunal en que, en última apelación, ha fallado el severo destino en este litigio terrible entre civilización y barbarie, entre la libertad y la esclavitud, entre las formas constitucionales y el poder absoluto. (“Despedida...” 104)

No quedaba ya, pues, instancia superior a la que apelar: ¡el suelo había sido regado de sal!; lo inconcebible había acaecido. Definitivamente, la historia en el Plata había entrado, ahora sí, en una "nueva era” (ésa a la que no podía aún definir). "Va a erigirse en la República Argentina un poder extraño, siniestro, contrario a todas las ideas recibidas; un poder que ha abjurado de todos los principios políticos que la razón, la justicia y la filosofía consagran como únicos e imprescindibles fundamentos de toda organización social” ("La revolución argentina”102). Destruida toda oposición, borrada toda posibilidad de derribar lo que se había convertido en "una tiranía sin nombre ni ejemplo”, se imponía al menos una reflexión sobre lo ocurrido. “¿Y este espectáculo terrible”, preguntaba, "no tiene lecciones útiles para nosotros?” ("La revolución argentina” 102). La razón debería entonces hundir su mirada en el fondo oscuro de la sociedad que había engendrado semejante monstruo. Así, la fórmula que Sarmiento originalmente concibió como un dispositivo categorial para fundamentar por qué la lucha, una vez planteada en los términos de un enfrentamiento entre civilización y barbarie, sólo podía conducir al triunfo del primero de ambos, tendría que contorsionarse para terminar, paradójicamente, sirviendo de marco para pensar precisamente aquello que tal fórmula excluía conceptualmente como posibilidad -la derrota de la civilización en manos de la barbarie.

LA COLISIÓN DE DOS MUNDOS

Si la afirmación de Rosas representaba algo monstruoso para Sarmiento, es porque trastrocaba las coordenadas que ordenaban el mundo, según él lo concebía. Civilización y barbarie representaban, en su visión del mismo, dos universos de sentido cerrados y mortalmente enfrentados entre sí. Como decía Tulio Halperín Donghi, "falta así en Facundo todo lo que hallamos ambiguo e indiferenciado en la historia que ante nuestros ojos se desarrolla; todo está orientado y polarizado, nada puede ser neutro ni indiferente en esa gran lucha que hiende la realidad histórica hasta sus abismos” (26). Desde el punto de vista del diseño y estructura de la obra, “civilización” y "barbarie” son más que los dos términos de una antinomia radical, marcan lo que Thomas Pavel llama "dominios semánticos", es decir, "conjuntos de proposiciones que describen configuraciones ontológicas, dan información epistemológica y axiológica relevante, y listan las máximas 
de la acción” (50). Facundo es, en fin, un cuaderno de bitácora, el trazado cartográfico, "la carta geográfica de las ideas y los intereses que se agitaban” (106), en la que se "clasifican distintamente los elementos contrarios, invencibles, que se chocan" buscando volver familiar, transitable, "este nuevo modo de ser que no tiene antecedentes bien marcados y conocidos” (10). Tras la derrota, dicho esquema, lejos de abandonarse, se refuerza. No obstante, el mismo no podría mantenerse incólume, como cuando ambas categorías polares que lo tensionan se encontraban en su lugar apropiado. Porque existe una cierta lógica presupuesta en la base de dicho modelo que la afirmación de Rosas habría, sin embargo, quebrado.

El esquema civilización-barbarie no sólo distribuye los espacios y define los horizontes de inteligibilidad, sino que importa también una dinámica, una direccionalidad (un telos): en su lucha recíproca, la civilización debe necesariamente imponerse, porque la barbarie es la pura materia, inercia, mera resistencia, pero nunca un principio activo, porque no tiene historia (no forma parte de la Historia) en la medida en que es precisamente su negación. Y, sin embargo, con Rosas se produce lo inconcebible dentro de dicho esquema. Rosas es, como en Amalia de José Mármol, aquel elemento incontrolable (indefinible) que se introduce en el círculo de la palabra escrita (el circuito epistolar trazado por Daniel Bello, mediante el cual, como un demiurgo, se proponía orientar y dirigir la Historia hacia su desemboque racional a espaldas de sus mismos actores $)^{10}$ y lo desquicia, colocando en su lugar un otro orden que representa su completa negación (Rosas y su cuñada, doña María Josefa Ezcurra, son los únicos completamente impermeables a los designios del joven Bello y capaces de tramar sus propias intrigas). Ésta era, según decía Cándido -quien enseñó a Daniel y a todo Buenos Aires a escribir-, una “casa... para la que no se halla una perfecta definición gramatical” (Mármol, Amalia 446). En fin, Rosas, como figura, violaba las leyes de la Historia desde dentro de la Historia, trastrocaba aquellas leyes cuya validez el proceso de su emergencia sin embargo presuponía (y sólo así podía hacerlo, dado que de lo contrario habría permanecido como un mero accidente sin importancia histórica).

La lucha contra Rosas, tal como la concibe Sarmiento, no podría, pues, reducirse al carácter de una mera anomalía focalizada, una “desviación local”. Ésta tenía, para él, una significación histórico-universal, venía a plantear una problemática relativa a la lógica misma de la Historia (con mayúsculas) y que afectaba a su propio concepto. "Lo que había sido una discusión oscura y sólo interesante para la República Argentina, lo es, ahora para la América entera y la Europa”, asegura, “es una cuestión del mundo cristiano” (Facundo 237). Y sólo en este sentido es que puede hablarse del régimen rosista como de una anomalía histórica (o mejor dicho, Histórica), que dio lugar “a escenas tan peculiares, tan características y tan fuera del círculo de ideas en que se ha educado el espíritu europeo”

\footnotetext{
10 “-Este hombre hará cuanto le digo - dijo Daniel, después de escribir la carta, con un acento de absoluta confianza-. Este hombre y todos los demás de su especie, devorarían a Rosas sin saberlo ellos, si solamente hubiera tres hombres como yo que me ayudasen a conducirlos; uno en la campaña, otro en el ejército, otro cerca de Rosas, y yo en todas partes como Dios, o como el diablo... Me falta otra carta todavía - continuó, abriendo un secreto de su escritorio y sacando un papel lleno de signos convencionales, que consultaba a medida que escribía con ellos” (Mármol, Amalia 40).
} 
(39). No sólo porque violaba, transgredía las leyes humanas y naturales, sino porque al hacerlo revelaba también al mundo, a la civilización, la miseria de su razón, de su ciencia.

¡Rosas! ¡Rosas! ¡Rosas¡, ¡me posterno y humillo ante tu poderosa inteligencia! ¡Sois grande como el Plata, como los Andesi ¡Sólo tú has comprendido cuán despreciable es la especie humana, sus libertades, su ciencia y su orgullo! ¡Pisoteadla! (179)

De allí que "la historia de la tiranía de Rosas” fuera, para Sarmiento, "la más solemne, la más sublime y la más triste página de la especie humana” “"Carta a Valentín Alsina” 20) (y también la más problemática). El fenómeno de la afirmación de un "orden bárbaro” representaría la emergencia de algo para lo que los términos provistos por la Cultura -los únicos, por otra parte, con los que podría intentarse dar cuenta racional de él- no encontraban expresión. ${ }^{11}$ Sarmiento lo llamaría "el legislador de esta sociedad tártara... sin nombre aún en la Historia” (86), en fin, un obvio oxímoron (la sociedad tártara se define, precisamente, por la ausencia de toda ley objetiva). Para dotarlo de una cierta presencia discursiva debería, pues, torsionarse el lenguaje. La violencia empírica que impuso Rosas sobre la Historia tendría así su contrapartida en la violencia simbólica que Sarmiento debería infligir sobre el sistema de la representación. Y es aquí que aparece Facundo. Éste no sólo posee la clave para descifrar este enigma, como anuncia en la famosa invocación con que abre esta obra (“Tú posees el secreto: ¡revélasnoslo!”). La apelación a la figura del caudillo como clave para explicar a Rosas es ella misma la encarnación del tipo de violencia operada sobre el sistema de la representación; condensa el dispositivo de referencia desviada necesario para designar aquello a lo que no puede referirse directamente, puesto que no tiene nombre que lo defina.

EL MYSTERIUM TREMENDUM

Aunque elemental y primitivo, Facundo, “expresión fiel de una manera de ser de un pueblo, de sus preocupaciones e instintos”, era también, a su modo, un Grande Hombre, “el hombre de genio, a su pesar, sin saberlo él, el César, el Tamerlán, el Mahoma” (86), "el espejo en que se reflejan, en dimensiones colosales, las creencias, necesidades, preocupaciones y hábitos de una nación en una época dada de su historia” (16). Y esto plantea ya un primer problema. Porque en la lógica de ese mundo dicotómico que nos ofrece Sarmiento, tensionado por la antinomia entre civilización y barbarie, donde los respectivos “dominios semánticos” se encuentran perfectamente delimitados, no cabe verdaderamente tal cosa como una Bárbaro-Grande Hombre. Esto llevó a Anderson Imbert a negar que para él Facundo pudiera serlo; “para Sarmiento”, decía, “un caudillo no es un grande hombre -sólo los creadores lo son- sino un tipo, una figura, una manifestación que refleja pasivamente el entorno” (55). Y en efecto, aquellas facultades que caracterizarían a los pobladores de la campaña argentina, frente a las cuales Sarmiento

11 "Por medio de la historia, de la filosofía, en fin, ha investigado para encontrar las propiedades absolutas del ser, a fuerza de recoger y comparar sus manifestaciones, y para construir sobre el alma, sobre Dios, sobre este mundo y el otro, un sistema, el verdadero, universal, sin multiplicidad de principios, unitario sin exclusión” (“Apertura de un cuento...” 300). 
no ocultaba su admiración, y que la figura de Facundo condensaría, lejos de constituir una fuerza creadora que permitía transformar y humanizar su medio social y natural, expresaban, por el contrario, una capacidad especial para adecuarse al mismo hasta terminar mimetizándose con él. Facundo no era más que la encarnación de esta habilidad mimética primitiva particular; él era el rastreador, el baqueano, el gaucho malo y el cantor reunidos. Pero en esto todavía no se distinguía de los demás caudillos, como López o Bustos. Sin embargo, Quiroga no era un caudillo más. Contra lo que afirmara Anderson Imbert, él era, sin embargo, para Sarmiento, un "grande hombre”, su biografía revela mucho más que la vida de un simple caudillo bárbaro, sin dejar por ello de serlo. Ella contiene uno de los núcleos del drama argentino, que preanuncia su desenlace paradójico.

Éste se inicia cuando "el Gobierno de Buenos Aires insta a Facundo que invada a Tucumán y restablezca las autoridades provinciales” (119). “He aquí la famosa acción del Tala, primer ensayo de Quiroga, fuera de los términos de su provincia. Ha vencido en ella, al valiente de los valientes [Lamadrid]” (120). "Desde este momento”, dice Sarmiento, "principia la vida pública de Facundo” (93). Ese hecho (el aventurarse fuera del ámbito de su provincia) lo distingue radicalmente de todos los demás caudillos.

Muy distinto de Ibarra o López, que no gustan sino de defenderse en su territorio, él acometerá el ajeno y se apoderará de él. Así la Providencia realiza las grandes cosas por medios insignificantes e inapercibibles, y la Unidad Bárbara de la República va a iniciarse, a causa de que un gaucho malo ha andado de provincia, levantando tapias y dando puñaladas. (115)

Facundo realiza entonces lo inconcebible, dota a la Barbarie de entidad política, “enlaza y eslabona todos los elementos de desorden que hasta antes de su aparición estaban agitándose aisladamente en cada provincia; él hace de la guerra local, la guerra nacional, argentina” (15). Se torna así ese "punto de enlace” por el que ambos universos cerrados, inconmensurables entre sí, según el esquema sarmientino, entran en contacto. Sarmiento lo llama un "momento solemne y crítico en la historia de todos los pueblos pastores de la República Argentina” (93). Porque entonces se produce una inflexión heterotópica (la colusión de elementos heterogéneos entre sí), cuando la razón, el mundo de la civilización, se ve confrontada ante su Otro radical (la barbarie; aquel "tercer elemento" que le es "heterogéneo”). Y si éste es un momento “solemne y crítico”, es porque es necesariamente violento (el de la guerra pura, en el que uno u otro bando debe perecer), un momento a veces incluso trágico para la civilización, pero siempre "sublime”, porque es también el momento creativo por excelencia en la Historia por el que la Civilización logra expandir sus fronteras más allá de lo que son sus dominios propios y colonizar a la Naturaleza.

Es aquí, sin embargo, que esta lógica se trastroca. Y ello nos conduce al segundo aspecto que encarna la figura del caudillo. Si Facundo contiene la clave de cómo nace Rosas, el proceso que llevaría a la entronización de la tiranía, muestra también todo lo que hay de inconcebible en éste. La escena en que entra a Buenos Aires, tras haber sido derrotado por Paz, ilustra esto. Autores como Noé Jitrik han prestado especial atención a esta escena en la que, según afirma Jitrik retomando una idea primero postulada por Ricardo Rojas, se descubre hasta qué punto Sarmiento se identificaría con su héroe (Facundo), tomando así claramente partido por el Interior contra el afán hegemónico de 
Buenos Aires. ${ }^{12}$ Esta interpretación parte de un hecho evidente. Es cierto que Sarmiento sentiría cierta “fascinación” por Facundo por el mismo hecho que él le proveía lo que los chilenos no tenían y los hundía, según decía, en la medianía intelectual: un tema. ${ }^{13}$ Deducir de allí una identidad secreta entre ambos resulta, sin embargo, en una lectura demasiado literal y sofisticada al mismo tiempo de la escena en cuestión. Ésta, más que revelar ciertas ocultas proyecciones subjetivas, basadas en secretas afinidades ideológicas o psicológicas del autor, cumple una función fundamental en el desarrollo de la trama, exponiendo las pistas para descifrar el enigma en torno al cual se organiza la obra entera (el "esfinge argentino" llamada Rosas).

Según muestra Sarmiento, el proceso por el cual Facundo logra someter al conjunto del país, convirtiéndose así en un caso único, anómalo (un caudillo que se instituye como líder a nivel nacional) tiene una explicación. Este fenómeno condensa un conjunto de anomalías históricas y naturales. Las “peculiaridades del suelo” argentino, su particular disposición geográfica y conformación social (su tendencia natural al centralismo), y una serie de acontecimientos aberrantes (como el que Lavalle abandone las técnicas militares europeas y adopte la táctica montonera) permiten comprender el proceso, en principio paradójico, por el cual nace ese "tercer elemento heterogéneo", es decir, cómo la "barbarie” adquiere entidad política. Pero de ningún modo explican a Rosas, esto es, cómo un caudillo pudo adueñarse de la ciudad. Porque un caudillo es, aun en aquellos casos como el de Facundo en que las circunstancias lo han convertido en un "grande hombre", a su pesar, una expresión del medio que lo rodea, un reflejo pasivo de su entorno. Por eso, cuando Facundo entra a Buenos Airees ("y bien pronto se ve rodeado de los hombres más notables”) (191), se civiliza ipso facto. De allí también que, aún después de producida lo que Jitrik llama su "transfiguración”, ni bien vuelva a la campaña renacerían en él sus instintos bárbaros. "La brutalidad y el terror vuelven a aparecer desde que se halla en el campo, en medio de aquella naturaleza y de aquella sociedad semibárbara” (194).

Si Facundo se regenera en Buenos Aires es porque, en definitiva, en tanto que caudillo, no podía permanecer como tal allí. En todo caso, sabía que en la ciudad (el lugar

${ }^{12}$ En Muerte y resurrección de Facundo, Jitrik afirma demostrar que "en el espíritu de Sarmiento la oposición Buenos Aires-Interior estaba perfectamente formulada, pero no sólo eso, sino que también frente a ella tomaba claro partido por uno de sus términos, el interior” (20). Según Jitrik, el que los críticos no advirtieran ello se debió a que en Sarmiento "termina por primar el esquema mental que sofoca la materia vivencial” (69). Ricardo Rojas inició esta línea de interpretación cuando afirmó que Sarmiento "escribió contra los gauchos, pero yo no le creo, porque estoy en el secreto: nadie se parecía más a Facundo que Sarmiento” (Rojas, El profeta de la pampa 171). Sobre la historia de las lecturas de la obra de Sarmiento, véase Palti, Sarmiento. Una aventura intelectual, cap. 1.

${ }^{13}$ Analizando el estado intelectual del país que le sirve de anfitrión, dice: "Pero son otras las causas que producen y mantienen esta especie de letargo: no hay una cuestión viva que agite los ánimos y ponga en actividad la inteligencia; no hay un blanco para que la juventud se ejercite; no hay objetos que provoquen su entusiasmo, su actividad y su deseo natural de ostentar su capacidad y sus luces. Désele, pues, un tema, un motivo de acción, un problema que resolver y se le verá entonces lanzarse con ardor en una carrera gloriosa y llena de encantos para ella” (“Creación de la Escuela...” 271). 
de la civilización) no podía actuar a su arbitrio, que allí existía “otro poder” más fuerte que el suyo: el de la Ley. ${ }^{14} \mathrm{Y}$ ante éste el caudillo debía sucumbir.

La Policía hace entrar sus satélites a la habitación misma de Quiroga, en persecución del huésped de la casa, y Facundo, que se ve tratado tan sin miramiento, extiende el brazo, coge el puñal, se endereza en la cama donde está recostado, y enseguida vuelve a reclinarse y abandona lentamente el arma homicida. Siente que hay allí otro poder que el suyo, y que pueden meterlo en la cárcel, si se hace justicia a sí mismo. (191)

¿Cómo pudo, entonces, instaurarse el arbitrio en las ciudades? Encontramos aquí la respuesta al enigma alrededor del cual gira esta obra. La afirmación de que “el enigma es Rosas” no es el interrogante que motoriza su trama sino la respuesta al mismo: decir que el nombre de "Rosas" es un interrogante, una gran " $X$ ", indefinible, incomprensible, es ya toda una definición. Ésta, sin embargo, lejos de resolver la cuestión, se desdobla en otra: ¿cómo representar entonces aquello que no puede concebirse? Una escena de Viajes, la escalada al Vesubio, "ese terrible laboratorio en que se fraguan los mas terribles fenómenos de la naturaleza” (Viajes por Europa... 244) (la analogía de la tiranía con un volcán es una de sus figuras más recurrentes) ${ }^{15}$ nos revela la turbación que lo asalta ante la vista de lo indescriptible.

Invitado por "un joven inglés, bello como un Adonis i atolondrado como un francés" (Viajes 245), nuestro autor inicia el ascenso (o, mejor dicho, el descenso) por “un valle que no vieron sin duda ni Virjilio ni el Dante, que a haberlos visto hubieran hecho de él la digna antecámara del infierno" (Viajes 245). "El vapor de azufre”, dice, "nos entraba hasta los pulmones, cuando el guia arrancándome un pañuelo me atacó con él la boca, como si se tratara de tapar un agujero" (Viajes 246). Finalmente llegaron a la cima para ver... lo mismo que veía el gaucho cuando miraba la pampa... ¡nada!

Dos pasos mas, i ya estábamos en el borde del cráter del volcán, desde donde pude ver... Oh horror! lo que vio Tito en el Sanctum Sanctorum... nada! Hai otro cráter subterráneo, i a causa de la configuración interna del esterior i las lavas incandescentes que lo rodean, no es posible allegarse demasiado a él. Esto no obstante las rodillas flaqueaban, i tiemblan las carnes al ver pasar a diez pasos delante de sí la gruesa columna de fuego, piedras i lavas encendidas, al mismo tiempo que a cada pequeña erupción el cono se mueve. (Viajes 246)

\footnotetext{
14 "Sabe una cierta vez que cierto boticario ha hablado con desprecio de sus actos de barbarie en el Interior. Facundo se dirige a su botica y lo interroga. El boticario le impone y le dice que allí no está en las provincias para atropellar a nadie impunemente. Este suceso llenó de placer a toda la ciudad de Buenos Aires” (194).

15 " $\mathrm{Al}$ ver las lavas ardientes que se revuelcan, se agitan, se chocan, bramando en este gran foco de lucha intestina, los que por más avisados se tienen han dicho: 'Es un volcán subalterno, sin nombre, de los muchos que aparecen en América; pronto se extinguirá'; y han vuelto a otra parte sus miradas, satisfechos de haber dado una respuesta tan fácil como exacta de los fenómenos sociales que sólo han visto en grupo y superficialmente” (9).
} 
El problema que entonces surgía era el de cómo volver y explicar que aquello que había visto, que eso que había barrido con tres ciudades y hacía temblar la tierra era... ¡no era nada!, un inmenso vacío, un agujero negro.

Algunos momentos después hallábame de nuevo entre los de la comitiva que me confundían a preguntas por saber las cosas estupendas que debia haber visto. He visto, decíasle yo, todo lo que hay que ver y que Udes. no han visto; empezando respuesta tan evasiva i misteriosa a fundir en los ánimos poco a poco la sospecha de que yo no habia visto nada absolutamente. (Viajes 248)

Volviendo ahora a nuestra pregunta anterior: ¿Qué es, pues, Facundo? Más que un programa o un proyecto político, Facundo es, primariamente, el intento por relatar esa "nada”, y llenarla con sentidos, para así tapar ese otro agujero, el de su boca que se había quedado sin habla. Es, sobre todo, un dispositivo para crear significados, una fórmula para producir un saber, para construir conceptos. Y esto nos devuelve al interrogante original, ¿por qué escribir sobre Facundo para hablar de Rosas?, lo que llamamos una estrategia oblicua de aproximación a su objeto. También aquí en la misma formulación de la pregunta está contenida ya la respuesta en la que convergen y se anudan las anteriores pistas ofrecidas. Si Sarmiento escribe sobre Facundo no sólo es porque, según vimos, él es la expresión más genuina de su medio (primera pista); tampoco únicamente porque encierra, según lo ya señalado, la clave para comprender uno de los nudos de la historia argentina reciente: cómo ambos mundos de su universo, civilización y barbarie, colisionan (segunda pista). Facundo, en tanto que expresión y clave, sirve, fundamentalmente, a Sarmiento, como una fórmula: la de cómo referirse a aquello que no se lo puede designar directamente, es decir, como epífora (etimológicamente: "mover de un polo a otro") o "referencia desviada” de esa "nada” llamada Rosas. Facundo, en fin, como texto, cabría considerarlo como una epifórica.

\section{FACUNDO COMO EPIFÓRICA}

La epífora de un palabra describe un desplazamiento (“de... a...”). ${ }^{16}$ De allí que el término "metáfora” (translatio), que es él mismo una metáfora espacial (en Aristóteles la phora es una de las modalidades del cambio, el cambio de lugar), se defina en términos de desviación (para ta kurion: alejado de lo corriente u ordinario). La "alegoría" (allotrios) es también una forma epifórica de referencia; significa colocar un "otro nombre” (allotrios) en lugar del "nombre propio" (kurion). En todos los casos, tal “desviación” implica una información y una ambigüedad. Todo enigma es, en el fondo, una forma de alegoría (la que normalmente -según el esquema clásico de enunciación tripartita-se expresa en la tercera de las estrofas) y toda alegoría contiene un enigma ${ }^{17}$ ("la esencia del enigma”, decía Aristóteles, “consiste en describir algo mediante una combinación verbalmente imposible; no se puede llegar al enigma mediante la simple combinación de

\footnotetext{
${ }^{16}$ Sobre la noción de epífora, véase Paul Ricoeur, La metáfora viva (28 y ss.).

${ }^{17}$ Véase Angus Fletcher, Allegory. The Theory of a Symbolic Mode (8).
} 
palabras ordinarias, pero sí mediante la combinación de metáforas”) (Aristóteles, Poética 1458). La epífora, por otro lado, es siempre creativa, presupone no un saber (epistçmç) sino una cierta habilidad particular ( $t e k n c ̧$ ), la capacidad (que, según Aristóteles, no puede enseñarse) para descubrir analogías o semejanzas. ${ }^{18}$

Como señala Ricardo Piglia, el sistema del saber que se despliega en Facundo descansa todo sobre la base provista por el mecanismo de las comparaciones, lo que explicaría la proliferación de las analogías a lo largo del texto: para Sarmiento algo se conoce si puede referirse a otra cosa ya definida (de la que se tiene ya un concepto o nombre propio) que se le asemeja y la explica. ${ }^{19}$ "Esta lógica”, dice Adriana Rodríguez Pérsico, "tiende a sepultar lo irrepetible bajo el modo de la analogía” (Un huracán llamado progreso 35). Toda comparación, sin embargo, marca también un distancia, dice siempre, como un viejo cuento de Mayorca, “Aixo era y no era”. La metáfora es lo que Roman Jakobson llamó una "referencia escindida”, que señala lo que una cosa es, pero también lo que ella no es. ${ }^{20}$ Su comprensión supone, en palabras de Bedell Stanford, ${ }^{21}$ una "visión estereoscópica”, la capacidad para mantener simultáneamente dos puntos de vista que nunca alcanzan a conciliarse. Mantener esta tensión es el desafío que se le presenta a Sarmiento. Él dirá siempre, como el gurú hindú de los Upanishads “neti-neti”, ni tal cosa ni la otra. La pampa, Rosas, etc., afirma una y otra vez que se parecen a tal o cual cosa, pero se diferencian en que (...); podrían comparárselos a (...) si no fuera porque (...), tienen el aspecto de (...) aunque carecen (....); y así con todas sus comparaciones (de allí la proliferación casi al infinito del juego de las metáforas). Porque es éste el único modo de referirse a aquello que no tiene verdaderamente definición y que ninguna analogía alcanza a describir completamente; aquello que, por cualesquier medios salvo los indirectos, resulta "irrepresentable", simplemente porque no tiene ejemplo conocido. Éste es el caso de la pampa, un fenómeno inaudito al que ninguna analogía alcanza a describir: el de una sociedad sin ningún tipo de sociabilidad, una república sin res pública.

No habiendo sociedad reunida, toda clase de gobierno se hace imposible.... Ignoro si el mundo moderno presenta un género de asociación tan monstruoso como éste. Es todo lo contrario al municipio romano, que reconcentraba en un recinto, toda la población, y de allí salía a labrar los campos circunvecinos.... Se asemeja a la antigua esloboda esclavona con la diferencia que aquella era agrícola, y por tanto, más susceptible de gobierno: el desparramo de la población no era tan extenso como éste. Se diferencia de la tribu

\footnotetext{
18 "Metaforizar bien -eu metapherein-” es "percibir bien las semejanzas-to to homoion theôrein" (Aristóteles, Poética 1459).

19 "Si Sarmiento se excede en su pasión, un poco salvaje, por la cultura es porque para él conocer es comparar. Todo adquiere sentido si es posible reconstruir las analogías entre lo que se quiere explicar y otra cosa que ya está juzgada y escrita. Para Sarmiento saber es descifrar el secreto de las analogías: la semejanza es la forma misteriosa, invisible, que hace visible el sentido. La cultura funciona sobre todo como un repertorio de ejemplos que pueden ser usados como términos de la comparación” [Piglia, “Notas sobre Facundo”, Punto de Vista III.8 (1980): 17].

${ }^{20}$ Ricoeur, "The Metaphorical Process as Cognition, Imagination, and Feeling”, en Seldon Sacks, comp., On Metaphor (151).

${ }^{21}$ Citado por Ricoeur, “The Metaphorical Process”, en Sacks, comp., On Metaphor (152).
} 
nómade, en que aquélla anda en sociedad siquiera, ya que no se posesiona el suelo. Es, en fin, algo parecido al feudalismo de la Edad Media... pero aquí falta el barón y el castillo feudal. Si el poder se levanta en el campo, es momentáneamente, ni se hereda ni puede conservarse, por falta de montañas y posiciones fuertes. De aquí resulta, que aun la tribu salvaje de la pampa está organizada mejor que nuestras campañas, para el desarrollo moral.... Pero lo que presenta de notable esta sociedad, en cuanto a su aspecto social, es su afinidad con la vida antigua, si por otra parte no tuviese una desemejanza radical, en que...., en una palabra, no hay res pública. El progreso moral, la cultura de la inteligencia descuidada en la tribu árabe o tártara, es aquí no sólo descuidada, sino imposible. (31)

Facundo es la mejor síntesis y ejemplo de designación epifórica. Como caudillo, expresión genuina de su medio, de "un orden de cosas, un sistema de asociación característico" de las pampas argentinas (primera pista), Facundo es y no es Rosas; marca a la vez aquello de que nace Rosas y también todo lo que hay de inconcebible en él (en la barbarie "hecha sistema"). Por eso es que para referirse a Rosas, Sarmiento debe escribir sobre Facundo. Porque a Rosas (ese gran "agujero negro", como la boca del Vesubio) no hay forma de designarlo directamente; sólo se lo puede referir epifóricamente, mostrando lo que él es y no es (neti-neti).

Esta estrategia de aproximación oblicua se despliega, a su vez, a lo largo de la obra, en una serie de artificios o mecanismos de representación desviada. La primera y más básica es la de reconocer un fenómeno a través de sus consecuencias (procedimiento sumamente eficaz que le permite a Sarmiento escuchar y apreciar un discurso de Thiers sin necesidad de entender francés, "yo sigo el discurso por los efectos que causa, un sordomudo habría comprendido perfectamente el sentido de aquella improvisacion”) (Viajes 112), descubriéndolo como su oculta "causa ausente". A Rosas, como al Vesubio, no lo podemos definir, pero podemos representarlo indirectamente describiendo la devastación que produjo, mostrando cómo arrasó con la civilización en las ciudades del Plata, en las que ya no se observan fracs (para Sarmiento, “toda civilización se expresa en trajes, y cada traje indica un sistema de ideas entero") (22), del mismo modo como el Vesubio se denuncia en el hecho de que "sepultó bajo lavas o cenizas a Herculano, Pompeya i Stabia" (Viajes 244).

El otro mecanismo de representación desviada a la que apela Sarmiento es lo que llamaremos, tomando una expresión de Kenneth Burke, "perspectiva por incongruencia” (24-25). Lavalle usando poncho, o Quiroga hablando de Constitución, son todos ejemplos de "perspectiva por incongruencia”. La "incongruencia” no necesariamente (salvo en su caso límite) supone una contradicción (no hay una contradicción, en el sentido lógico, en decir que "Lavalle usa poncho" -como sí lo habría en afirmar, por ejemplo, que "Lavalle usa y no usa poncho”-; la contradicción surge sólo cuando introducimos una consideración semántica). Pero siempre supone algo más que una contradicción (en el sentido lógico de la misma). Porque una contradicción (tal como se expresa en un oxímoron; v.g., "falsamente verdadero") coloca juntos dos términos antinómicos pero que se sitúan en un mismo plano de realidad, forman parte de un mismo módulo discursivo. La "incongruencia" (lo que Jean Cohen llama “impertinencia semántica”), por el contrario, supone la colusión de signos que corresponden a campos simbólicos diversos, términos que sólo cobran sentido dentro de sus “dominios semánticos” (volviendo a la expresión de Pavel) 
particulares. Lavalle usando poncho o Quiroga hablando de Constitución son "incongruencias", porque sitúan en un mismo plano de discurso elementos que corresponden, respectivamente, a los dos dominios semánticos opuestos, inconmensurables, dentro del universo categorial sarmientino (“civilización” y “barbarie”); constituyen, en fin, heterotopoi que revelan el trastrocamiento producido en el orden del discurso, dando expresión a lo que no cabe expresar lógicamente. En el punto límite de la incongruencia, la definición de Rosas como “el legislador de la sociedad tártara”-que es una “incongruencia oximorónica” (semántica y lógica al mismo tiempo, como decir un “orden-bárbaro”)simboliza el completo desquiciamiento de ese universo (el Dis-Orden) entonces producido, generando así un auténtico monstruo lingüístico, no sólo porque es un oxímoron, sino, y fundamentalmente, porque es una "incongruencia absoluta”, su expresión última llevada al límite del oxímoron.

Existe finalmente un procedimiento epifórico aun más efectivo, porque escapa, en realidad, al juego de las analogías (estáticas, por definición): el de la indexicalidad (entre un índice y aquello indicado hay, según lo señalado por Peirce, referencia mutua pero no analogía). A ese volcán, ese agujero negro llamado Rosas, no lo podemos definir, la mirada no puede penetrarlo, no podemos siquiera analogarlo con nada conocido, pero sí podemos demarcar su circunferencia, fijar sus límites y contornos, y rodearlo de un sistema de señales que nos indique su posición precisa, y también la distancia que media. La escena en que Facundo entra a Buenos Aires sirve nuevamente de ejemplo. Ella muestra que el caudillo riojano no sólo es y no es Rosas: él es, como clave, como hecho narrativo (y no sólo objeto de descripción), una encrucijada Histórica (segunda pista); sobre todo, un índice que apunta a Rosas, que se mueve en su dirección, aunque nunca llega; señala ese horizonte en que se sitúa Rosas al mismo tiempo que muestra por qué no se lo puede penetrar. Y por ello muere en el camino, cuando asoma al borde mismo de su abismo, donde la Barbarie ("hecha sistema”, Dis-Orden) irrumpe, señalando (indicando) el hito que marca su límite: Buenos Aires. El índice es, en fin, la forma primitiva de la inteligibilidad, la Ursprache, el esbozo primero de discernimiento en medio de la turbación y la desesperación del extraviado-exiliado (“yo desespero”, decía, “i sin embargo, empiezo a sentir barruntos, a sentir que la lójica late en mi espíritu; me parece que veo de cuando en cuando señales, columnas miliares, linderos que muestran el camino que ha de seguirse en este laberinto”) (Viajes 103).

Este conjunto de dispositivos intelectuales que se resumen en la idea de la "referencia desviada”, del procedimiento epifórico es, en definitiva, el modo que encuentra Sarmiento para quebrar esa imposibilidad de la literatura en contextos previos a la afirmación del Estado nacional de que habla Ricardo Piglia, o, mejor dicho, de esa necesidad-imposibilidad que surge con la emergencia de lo indecible. Rosas hace, a la vez, necesaria e imposible la literatura, exige la representación de lo irrepresentable, poniendo de este modo en juego una serie de mecanismos referenciales que, como señala Piglia, le permiten escapar a los constreñimientos racionales sin abismarse en la "poesía".

La poesía, dice, es la "prisión del no ser, del no poder emplearse” del lenguaje. Si Echeverría es un ejemplo, para Sarmiento, de "poeta culto" (distinto del cantor, el gauchopoeta para el que la poesía es emanación espontánea del medio que lo rodea), es porque es el cantor de la derrota, la resignación impotente ante la inmensidad de la barbarie. 
Echeverría es el poeta de la desesperación, el grito de la intelijencia pisoteada por los caballos de la pampa, el jemido del que a pié i solo, se encuentra rodeado de ganados alzados que rujen i caban la tierra en torno suyo, enseñándole sus aguzados cuernos. ¡Pobre Echeverría! Enfermo de espíritu i de cuerpo, trabajado por una imajinación de fuego, prófugo, sin asilo, i pensando donde nadie piensa... Buscando en los libros, en las constituciones, en las teorías, en los principios, la esplicacion del cataclismo que lo envuelve. (Viajes 54)

No hay allí aún literatura. Porque Echeverría, como Mármol, simplemente se propuso contar lo indecible ("Mármol es poeta, i es lástima que cante lo incantabile, la descomposición, el marasmo”)(Viajes 71) y entonces le salen puras imágenes, poesía; quedando así atrapado en el círculo de sus propias impresiones, llenando de fantasmagorías el vacío de la barbarie que lo rodea, en un "monólogo sublime a veces, estéril siempre... ¡Yo os disculpo, poetas arjentinos! Vuestras endechas protestarán por mucho tiempo contra la suerte de vuestra patria. Haced versos y poblad el rio de seres fantásticos” (Viajes 49).

Si para Sarmiento la poesía no era saber, mucho menos lo era saber americano opuesto al saber europeo. Porque para él no existía tal cosa, sino simplemente saber, aquél capaz de descubrirnos "las propiedades absolutas del ser, a fuerza de recoger y comparar sus manifestaciones, y para construir sobre el alma, sobre Dios, sobre este mundo y el otro, un sistema, el verdadero, universal, sin multiplicidad de principios, unitario sin exclusión" (“Apertura...” 300). Para Sarmiento, la cultura argentina no podía ser más que cultura (algo que para él era una obvia redundancia). ${ }^{22}$ "Traducir" ("nosotros para instruirnos necesitamos traducir, eternamente traducir”) (“Memoria...” 41) era, para el autor de Facundo, la tarea fundamental allí en los márgenes de la civilización.

Para los hombres eminentes de Europa la formación de las teorías, para nosotros los resultados clasificados ya. En Europa está el taller en que se fabrican los artefactos; aquí se aceptan, se aplican a las necesidades de la vida. No importa que ignoremos las complicadas maquinarias que los han producido. (“Apertura...” 301)

Es cierto, no obstante, que Sarmiento terminaría postulando la necesidad "momentánea” de apartarse de los modelos europeos a fin de describir las peculiaridades de la geografía y, “sobre todo”, de la historia local, es decir, la lucha entre civilización y barbarie. ${ }^{23}$ Pero inferir de ello la emergencia en Facundo de una suerte de saber opuesto

\footnotetext{
22 "Nuestra literatura es, pues, un reflejo pálido y medio apagado de aquella literatura europea, heredada de todas las literaturas de los pueblos que le han precedido; nuestra política es un remedo, y remedo a veces sin inteligencia, de las instituciones europeas.... ¿Dónde, pues, iríamos a estudiar nuestra propia historia política y literaria, sino en la fuente misma de donde ella emana?" ("Apertura de un cuarto...” 300).

23 "Si un destello de literatura nacional puede brillar momentáneamente en las nuevas sociedades americanas, es el que resultará de la descripción de las grandiosas escenas naturales, y, sobre todo, de la lucha entre la civilización europea y la barbarie indígena, entre la inteligencia y la materia, lucha imponente en América, y que da lugar a escenas tan peculiares, tan características y tan fuera del círculo de ideas que se ha educado el espíritu europeo” (Sarmiento, Facundo, 39).
} 
al europeo no sólo no corresponde a la idea de Sarmiento del mismo (Garrels, "Traducir...” 272) sino, fundamentalmente, tiende a disolver esa tensión fundamental de la que nace esta obra, que es, como señala Piglia, la que surge de su propia imposibilidad, la imposibilidad de la literatura. Mejor dicho, de la simultánea necesidad-imposibilidad de la literatura que genera la indecibilidad del fenómeno Rosas. Si para Sarmiento hubiera sido posible inscribir al mismo dentro de un otro régimen de discurso distinto del racional, si hubiera sido concebible algo así como un saber distinto del europeo, simplemente no se habría producido tal tensión, la apelación a la literatura no habría aparecido como problema. Pero tampoco habría escrito Facundo. Quizás todavía habría, en la expresión de Piglia, fundado la literatura argentina, pero, en tal caso, definitivamente habría sido otra literatura argentina. Es esa necesidad-imposibilidad de la literatura en Facundo la que sirve de registro (replica, re-produce) a la necesidad-imposibilidad de la Historia en el Plata; precisamente porque, en la medida en que la última plantea un problema de naturaleza esencialmente epistemológica antes que política (un enigma), se identifica con la primera. $\mathrm{Y}$, fundamentalmente, porque ninguno de ambos alcanzan a resolverse en Facundo.

El procedimiento de la "referencia desviada" no le ofrecía verdaderamente una respuesta a ese enigma llamado Rosas, como tampoco, como señala Halperín Donghi, le permitiría concebir una alternativa a esa fisura que su entronización habría instaurado en el curso Histórico nacional (y que él imaginaba como un derrumbe colosal, de dimensiones épicas); sí le aporta, sin embargo, algo mucho más decisivo a los efectos de la composición de Facundo: una vía para confrontar ese enigma en tanto que tal (que es la "respuesta" implícita en Facundo: que "el enigma es Rosas"). Cuando Sarmiento se propone dar cuenta de la "barbarie americana” y así revelarles a los "hombres europeos” sus limitaciones ("hay una justicia ejemplar que hacer y una gloria que adquirir como escritor argentino: fustigar al mundo y humillar la soberbia de los grandes de la tierra, llámese sabios o gobiernos”) (21); es decir, cuando intenta dejar de "traducir” (sencillamente, porque no existe traducción posible para ese referente "Rosas") no es para crear una "saber americano" (aunque tampoco se trata, como agudamente señala Julio Ramos, de articular alguna forma degradada de saber) (Ramos, Desencuentros... cap. 1). Se trata para él más bien de apropiarse de los medios de producción de saber, ya no de los "artefactos" sino de su "taller". ${ }^{24}$ Esta necesidad del lenguaje de volverse creativo se liga, en última instancia, a la creatividad propia a la lucha entre "civilización y barbarie”, cuando ambos mundos colisionan y producen ese momento "solemne" en que la cultura se expande e incorpora nuevos dominios. Esto la obliga, pues, a confrontarse con lo desconocido para ella; para asirlo, definirlo, debe entonces hacerse productiva. La epífora sería la forma de la productividad del saber (Gadamer, Truth and Method 428-438), el taller que Sarmiento descubre del que salen los artefactos de la cultura ("la complicada maquinaria que los ha producido”). En definitiva, el no resolver ese enigma es lo que le permitiría instalarse en (y explotar) ese espacio de ambigüedad (anfibología) inherente a la alegoría.

\footnotetext{
24 “El que tal hiciera”, asegura en su carta a Alsina, “podría presentarse en Europa con su libro en la mano, y decir a la Francia y a la Inglaterra, a la Monarquía y al Times y a la Presse: “¡Leed, miserables, y humillaos! ¡He aquí vuestro hombre!”, y hacer efectivo aquel ecce homo, tan mal señalado por los poderosos, al desprecio y al asco de los pueblos!” (Sarmiento, Facundo 20).
} 
La metáfora (Ricoeur, La metáfora viva 23-46), como dijimos, significa la transposición de un "nombre extraño” (allotrios), es decir, “que designa a otra cosa”, “que pertenece a otra cosa” (Aristóteles, Poética 1457), para colocarlo en el lugar (anti) del "nombre propio” o “corriente” (kurion) (la metáfora representa, pues, una para-doxa -lo alejado del saber vulgar, doxa). Mediante la transposición se produce también un trastrocamiento del orden del lenguaje (el anti señala este des-orden: se toma el género por la especie, etc.); de allí la “anfibología” (ambigüedad) de la metáfora. Sin embargo, una de sus propiedades, que es la de poder sustituirse, permite siempre, invirtiendo el procedimiento, reemplazar el "nombre extraño" (alegórico) y restituir así el "nombre propio". En este sentido, lo alegórico aparece como un mero “adorno”, que sólo aporta energeia (vividez) a la descripción de una cosa ya perfectamente definida y cuyo "nombre propio" se encuentra siempre disponible. No ocurre lo mismo, sin embargo, cuando carecemos de éste, como sería el caso que nos ocupa. Aquí ya la alegoría dejaría de ser sólo ornamental para convertirse en definitoria (es decir, hace las veces de una definición) y creativa (en el sentido que implica un “descubrimiento”), aportando sentidos a eso (colocado en su centro) que no se puede definir propiamente.

Esto, sin embargo, plantea el riesgo cierto de un círculo infinito (el "vértigo de la hipérbole” del que hablaría Baudelaire). El mecanismo de la "referencia desviada” tiende, efectivamente, a retroalimentarse: el decir lo que Rosas, o la pampa, es y no es lleva siempre a una nueva comparación para mostrar también aquello otro que éste es y no es, y así al infinito. En última instancia, tiende a tornarse un círculo vicioso. Tomando la terminología de I. A. Richards (The Philodophy of Rhetoric), la alegoría presupone siempre un "dato” o tenor (v.g., “Aquiles”) a quien atribuir la "transmisión” o vehículo (v.g., “un león”). De lo contrario, el procedimiento alegórico girará permanentemente en el vacío. Sarmiento, de hecho, sabía (y sus contemporáneos, como Alsina y Gutiérrez, no dejaron de señalárselo) que el juego de sus analogías lo llevaban al borde del exceso, al límite de lo inverosímil (y, muchas veces, lo traspasaba: Facundo tenía “mucha poesía” para ser una "verdadera historia social”, según él se proponía, le reprochaba Alsina). ${ }^{25}$

La única forma de frenar este deslizamiento, cortar el círculo infinito de las “imágenes”, era mediante la imposición de un concepto, un nombre propio, a fin de suplir esa carencia. ${ }^{26}$ Pero esto planteará, a su vez, el problema del acto de primitivo de la nominalización; la "metáfora inicial” (cruda, sin referencia anterior posible) por la que algo se designa, se le atribuye ese "nombre propio" (se lo "marca”, como al ganado en la estancia), señalando ese "grado cero" respecto del cual cualquier "desviación” ulterior pueda medirse (lo que necesariamente hace nacer la sospecha de que el lenguaje todo no es más que un conjunto de metáforas sedimentadas).

${ }^{25}$ Según señala Alsina en su carta ya citada, "en su libro, que tantas y tan admirables cosas tiene, me parece entrever un defecto general -el de la exageración: creo que tiene mucha poesía, sino en las ideas, al menos en los modos de locución-Ud. no se propone escribir un romance, ni una epopeya, sino una verdadera historia social” (Sarmiento, Facundo 255).

${ }^{26} \mathrm{Si}$, como afirma Piglia, por analogía pudiera fijarse dicho concepto en la relación con aquello que sí se encuentra ya definido, el mecanismo de las comparaciones podría entonces estabilizarse. 
El acto de la nominalización se descubre así como el acto creativo por excelencia, pero también como uno de extrema violencia (la metáfora es también llamada catachresis -un abuso del lenguaje- que, según Quintiliano, se produce "porque es necesaria” para suplir una carencia del lenguaje) (Véase Parker, "Metaphor and Catachresis” 60-76). Esa creatividad-violencia de la nominalización resulta, en última instancia, correlativa, en Sarmiento, a la creatividad-violencia de la confrontación entre "civilización y barbarie”; ese “momento solemne”. En este sentido, la nominalización en sí misma no plantearía un problema para Sarmiento -de hecho, se convertiría en una de sus obsesiones más sistemáticas; especialmente, el grabado en piedras (“ad perpetuam rei memoriam”) (Viajes 22) de su propio nombre -en señal de dominio y posesión-, que va a rayar en él en una verdadera manía. ${ }^{27}$ De todos modos, a fin de disolver el potencial perturbador de la nominalización era necesario inscribir tal acto de violencia dentro de una lógica evolutiva, instituirlo como un momento necesario dentro de un curso racional que lo comprendiese, que es, precisamente, lo que en Facundo aún Sarmiento no logra (como sí lo hace en Recuerdos de provincia [1850]; pero para ello habría que esperar a que el sistema de alianzas montado por Rosas comenzase a revelar sus fisuras, no así hacia 1845, cuando el régimen rosista aparecía como un hecho incontrovertible). El no poder hacerlo haría de Facundo, pues, una novela fallida.

En efecto, de acuerdo con los parámetros tradicionales de la novela histórica del periodo, se observa en Facundo un desequilibrio fundamental. El prolijo análisis de la vida de Facundo, la lograda descripción (a la que le debe esta obra gran parte de su fama) de la perfecta armonía existente entre este hombre y su medio, entre los personajes cotidianos de la campaña (el baqueano, el rastreador, el cantor, el gaucho malo) y la personalidad de su héroe, contrasta palmariamente con la descripción sumaria y superficial de la vida y la personalidad de Paz, su contraparte civilizada. En definitiva, si la lucha es entre “civilización y barbarie”, sólo hay historia aquí de lo que es su negación, es decir, la historia de Quiroga, de Rosas, en fin, de la Barbarie. Falta la historia de aquello que constituye su ámbito propio, la de las ciudades, la de sus grandes hombres y sus personajes cotidianos, la "Historia de la Civilización”, ${ }^{28}$

No sería así, sin embargo, si pensamos que lo que subentiende en ella es un problema aun anterior a la propia del género (descubrir la lógica oculta que ordena los acontecimientos

\footnotetext{
${ }^{27}$ Dos de estos hechos son particularmente sugerentes. Uno, al comienzo de sus Viajes, en la isla de Más-a-Fuera, donde supuestamente residió Robinson Crusoe. El otro, ya caído Rosas, en la isla Martín García, convertida en el lugar de su utopía, donde habría de instaurarse la capital que habría de dotar de un orden definitivo a la república. Ambos lugares marcan, respectivamente, el comienzo y el fin supuesto por Sarmiento de la Historia, o al menos su Historia.

${ }^{28}$ Según señala Sarmiento, si Paz pudo quizás haber triunfado militarmente sobre Rosas, no fue fortuito que no lo hubiera hecho; porque, si él era la contracara de Quiroga, luego era la manifestación de una tendencia espontánea de unidad nacional, expresaba "los primeros ensayos de fusión" provenientes, en este caso, del término civilizado de la contradicción. Por eso podía vencer a Quiroga, pero Rosas era ya otra cosa, porque sólo él habría logrado convertirse en la verdadera síntesis de los diversos factores en pugna (sólo que en este caso el rol de "polo activo” lo cumpliría el factor incivilizado). Paz podía ser el anti-Facundo, pero no llegaría a elevarse a la altura de un antiRosas, y por ello debía de ser derrotado “por el gaucho de la pampa convertido en elemento político”. Ante la "barbarie hecha sistema", era ya impotente.
} 
en un sentido evolutivo -mimçsis physeôs), lo que conlleva una perspectiva opuesta a la anterior. En definitiva, si Sarmiento no logró darle un remate a su historia, integrar el acto de la pura violencia (la conquista de la barbarie) dentro de un cuadro evolutivo orgánico que la legitime, no fue porque no pudiera recentrar su eje dinámico en el polo civilizado de la contradicción, sino a la inversa: éste no lograría recentrar su narrativa en su locus natural porque no alcanzaba aún a concebir ese momento de violencia que reinstalase a la Historia dentro de su curso orgánico natural. El punto es que, desde esta nueva perspectiva, tal deficiencia no la haría ya una novela fallida, simplemente porque no sería éste (trazar un curso genealógico de la nación) su objeto, el trasfondo de problemas respecto del cual cabría analizar a Facundo como obra. De hecho, si tomamos en cuenta el tipo de dispositivos de saber que en ella se encuentran operando, no es siquiera una novela en el sentido antes definido.

La irresolución del enigma y la consecuente problematización del acto de la nominalización lleva a Sarmiento, en efecto, a alterar el régimen mimético que estructura esta obra. Como vimos, el sistema referencial que funciona en la novela tradicional es el de la mimçsis physeôs: el tipo de analogía que des-cubre (y postula) la existencia de un orden de realidad subyacente, oculto a la mirada (el physis de la expresión indica precisamente esa dimensión situada más allá de lo fenoménico). La “referencia desviada”, por el contrario, nos enfrenta a la violencia de la nominalización (de la catachresis). No existe un Orden subyacente que Sarmiento busca descubrir, sino un Dis-Orden al que trata de entender. Y sólo ese no-poder de la Historia hace que el enigma pueda hacerse visible como tal. La violencia que entonces se nos revela resultaría aquí no tanto del hecho de que la nominalización supondría un acto de dominio (una “marca”), sino, fundamentalmente, porque conllevaría antes una transgresión del orden natural del lenguaje (el anti de la metáfora; las “incongruencias” o heterotopoi). Había que violentar el lenguaje para dar cabida a un fenómeno que no podía asimilarse a sus categorías; es decir, volverlo creativo para llenar una carencia (como decía Quintiliano). Facundo, en este sentido, no es una novela fallida, pero tampoco una novela tradicional, según el esquema de la mimçsis physeôs (ese otro supuesto Orden, el de la civilización, se halla en él por completo ausente); es más bien una anti-novela (anti: “en el lugar de”), la novela del exilio, aquella en que la forma novelística se encuentra al mismo tiempo presupuesta y trastrocada (en ella, como vimos, se disloca el esquema de la novela tradicional no invirtiendo su forma sino quebrando su lógica). El instalarse en el centro mismo del enigma llamado Rosas (no buscando una respuesta al mismo, sino haciendo de él la respuesta) le permite así a Sarmiento confrontar aquello que aparece como inconcebible dentro de su universo categorial, indecible, asomarse -como a la boca de un volcán- precisamente a eso que la novela tradicional debe obliterar para generar una historia concebida según las pautas del historicismo romántico (la de la travesía -Bildung- del héroe del caos aparente al Orden subyacente) $)^{29}$ : esa instancia irracional de violencia-creatividad (el acto de la nominalización primero, la pura metáfora, infundamentada) que se encuentra en la base de todo Orden.

\footnotetext{
${ }^{29}$ La palabra alemana “Bildung” contiene la raíz “Bild” que significa "imagen” o, más precisamente, “cuadro”. Ésta refiere así al proceso de formación del sujeto de acuerdo a una "imagen” ideal del hombre y el mundo.
} 
BiBLIOGRAFÍA

Alberdi, Fragmento preliminar al estudio del derecho. Buenos Aires: Biblos, 1984.

Anderson Imbert, Enrique. Genio y figura de Sarmiento. Buenos Aires: Eudeba, 1988.

Aristóteles, Horacio, Boileau. Poéticas. Edición preparada por Aníbal González Pérez. Madrid: Editora Nacional, 1982.

Burke, Kenneth. "Rhetoric, Poetics, and Philosophy". Rhetoric, Philosphy, and Literature. An Exploration. Don M. Burks, comp. West Lafayette, IN: Purdue University Press, 1978. 24-25.

Fletcher, Angus. Allegory. The Theory of a Symbolic Mode. Ithaca/Londres: Cornell University Press, 1995.

Gadamer, Hans-Georg. Truth and Method. New York: Crossroad, 1992.

Garrels, Elizabeth. "Traducir a América: Sarmiento y el proyecto de una literatura nacional”. Revista de Crítica Literaria Latinoamericana XIX/8 (1993): 272.

Halperín Donghi, Tulio. “Facundo y el historicismo romántico”. Ensayos de historiografía. Buenos Aires: El Cielo por Asalto, 1996. 26.

Hirschman, Albert. The Passions and the Interests. Political Arguments for Capitalism Before its Triumph. Princeton: Princeton University Press, 1977.

Jitrik, Noé. Muerte y resurrección de Facundo. Buenos Aires: CEAL, 1983.

Mármol, José. Amalia. La Habana: Casa de las Américas, 1976.

Palti, Elías. Aporías. Tiempo. Modernidad. Sujeto. Historia. Nación. Ley. Buenos Aires: Alianza, 2001.

Sarmiento. Una aventura intelectual. Buenos Aires: Instituto Dr. E. Ravignani UBA-, 1991.

"Reseña-Ensayo: Hans Blumenberg. Sobre la modernidad, la historia, y los límites de la razón”. Revista Latinoamericana de Filosofía 22/2 (Primavera de 1996).

Parker, Patricia. "Metaphor and Catachresis". The Ends of Rhetoric. History, Theory, Practice. John Bender y David Wellerby, comps. Stanford: Stanford University Press, 1990.

Pavel, Thomas. The Poetics of Plot The Case of English Renaissance Drama. Minneapolis: University of Minnesota Press, 1985.

Piglia, Ricardo. “Notas sobre Facundo”. Punto de Vista III/8 (marzo-junio, 1980): 1518.

Ramos, Julio. Desencuentros de la modernidad en América Latina. Literatura y política en el siglo XIX. México: FCE, 1989.

Richards, I.A. The Philosophy of Rhetoric. Oxford: Oxford University Press, 1936.

Ricoeur, Paul. La metáfora viva. Madrid: Cristiandad, 1980.

"The Metaphorical Process as Cognition, Imagination, and Feeleing”. On Metaphor. Seldon Sacks, comp. Chicago: The University of Chicago Press, 1979.

Rodríguez Pérsico, Adriana. Un huracán llamado progreso. Washington, DC: OEA, 1988.

Rojas, Ricardo. El profeta de la pampa. Buenos Aires: Losada, 1945.

Sarmiento. Viajes por Europa, África i América, 1845-1847. Madrid: Archivos, CSIC/ FCE, 1993. 
Facundo. Buenos Aires: Biblioteca Ayacucho/Hyspamérica,1986.

“Carta a Valentín Alsina”. Facundo. Buenos Aires: Biblioteca Ayacucho/ Hyspamérica, 1986. 20.

“Segundo comunicado”. El Progreso (10/12/1842); en Obras completas, II: 59.

“Origen de la fiesta de Nochebuena”. El Progreso (21/12/1842); en Obras completas II. (Buenos Aires: Luz del día, 1948-51): 91.

“Ensayo sobre la vida y escritos de D. Manuel J. Gandarillas”. El Progreso (5/12/ 1842); en Obras completas, III: 245.

“Apertura de un curso de historia en el Colegio de Santiago”. El Progreso (10/4/ 1843); en Obras completas, IV: 300.

“Memoria sobre ortografía americana”. El Progreso (17/10/1843); en Obras completas, IV: 41.

“Creación de la Escuela Normal de Preceptores”, El Progreso (23/3/1842); en Obras completas, IV: 271.

“La revolución argentina”. El Progreso (11/1/1843); en Obras completas, VI: 9899.

“Despedida de El Heraldo Argentino”. El Progreso (11/1/1843); en Obras completas, VI: 104.

"Prospecto del Heraldo Argentino a los residentes en Chile”; El Heraldo Argentino (23/12/1842); en Obras completas, VI: 94 y 97.

"Conducta de Rosas y sus agentes con el gobierno de Chile”. El Mercurio (19/4/ 1842); en Obras completas, VI: 34-5.

“Comentario de las noticias argentinas”. El Mercurio (30/4/1842); en Obras completas, VI: 47-8.

"Prospecto del Heraldo Argentino a los residentes en Chile”. El Heraldo Argentino (23/12/1842); en Obras completas, VI: 94 y 97.

"Vindicación de la República Argentina en sus revoluciones y en sus guerras civiles”. El Mercurio (7/6/1841); en Obras completas, VI: 9.

“La cuestión del Plata”. El Mercurio (13/10/1842); en Obras completas (Buenos Aires: Luz del día, 1948-1951), VI: 77.

“Política americana”. El Nacional (14/4/1841); en Obras completas, IX: 17.

Stegmüller, Wolfgang. Estructura y dinámica de teorías. Barcelona: Ariel, 1983.

Tatarkiewicz, Wladyslaw. Historia de seis ideas. Madrid: Tecnos, 1995. 